\title{
Effects of Carbon Emissions, Environmental Disclosures and CSR Assurance on Cost of Equity in Emerging Markets
}

\author{
Renato Garzón-Jiménez ${ }^{1, *}$ and Ana Zorio-Grima ${ }^{2}$ (D) \\ 1 Faculty of Economics and Business, Universidad Católica de Santiago de Guayaquil, \\ Av Carlos Julio Arosemena Km 1,2, Guayaquil 090150, Ecuador \\ 2 Faculty of Economics, Department of Accouting, Universitat de Valencia, Av. De Tarongers, s/n, \\ 46022 Valencia, Spain; ana.zorio@uv.es \\ * Correspondence: luis.garzon@cu.ucsg.edu.ec
}

Citation: Garzón-Jiménez, R.; Zorio-Grima, A. Effects of Carbon Emissions, Environmental Disclosures and CSR Assurance on Cost of Equity in Emerging Markets. Sustainability 2021, 13, 696. https:// doi.org/10.3390/su13020696

Received: 23 December 2020 Accepted: 9 January 2021 Published: 13 January 2021

Publisher's Note: MDPI stays neutral with regard to jurisdictional clai$\mathrm{ms}$ in published maps and institutional affiliations.

Copyright: (C) 2021 by the authors. Licensee MDPI, Basel, Switzerland. This article is an open access article distributed under the terms and conditions of the Creative Commons Attribution (CC BY) license (https:// creativecommons.org/licenses/by/ $4.0 /)$.

\begin{abstract}
The objective of the paper is to empirically test the relation between carbon emissions, environmental disclosures, assurance of sustainability reports and firms' Cost of Equity (COE) measured by an Ex-Ante proxy model. The methodological approach uses the Generalized Method of Moments (GMM) required to control endogeneity problems using a sample of 929 firms that are included in the Morgan Stanley Emerging Market Index. The data panel includes 5328 observations from 30 emerging countries covering the period 2014 to 2019. Our results indicate that firms with higher carbon emissions have higher COE, which implies that capital providers penalize highly polluting firms. Contrarily, evidence shows that firms with greater environmental disclosures, and the those who externally assure their corporate social responsibility reports decrease their COE. Our study expands the literature regarding carbon emissions and its relation with firms' COE from an emerging market perspective covering a multi-country sample, with findings that confirm that higher emitters are penalized in terms of COE. Moreover, our research confirms in this setting the negative relation between environmental, social and governance disclosure scores and COE. Moreover, we evidence as well that the assurance of sustainability reports also promotes legitimacy and decreases information asymmetries, in the sense of reducing COE. The value of our findings is especially relevant as it may encourage listed companies in emerging countries to engage in more sustainable practices-e.g., reduce carbon emissions.
\end{abstract}

Keywords: $\mathrm{CO}_{2}$ emissions; Cost of Equity; assurance; environmental disclosure; emerging markets

\section{Introduction}

Nowadays, climate change has become an important subject for the global economy. Many countries have defined targets for carbon emission reductions by 2030 - e.g., the European Union aims to reduce Greenhouse Gas (GHG) emissions by $40 \%$ and China aims to do so by $65 \%$ by implementing an emission trading scheme similar to the European Union's [1]. There is a global concern on GHG emissions because with no further actions to reduce them, global warming is expected to increase by 2 degrees Celsius above the pre-industrial baseline. Moreover, climate change disasters are accountable for 3 billion US dollars in economic losses claiming 1.3 million lives between 1998 to 2017 [2]. Nowadays, just 12 countries in the world (i.e., the G7-France, Germany, Italy, Japan, the United Kingdom, the United States and Canada-and the BRICS-Brazil, Russia, India, China, and South Africa-considered a "rising power" by Lemma et al. [3] are responsible for 60\% of global Greenhouse Gas (GHG) emissions as in 2017 [4].

Over the counter and equity markets may represent a source of capital to finance activities related to the 13th Sustainable Development Goal (climate action) taking into account disclosures on Environmental, Social and Governance (ESG) or (Corporate Social Responsibility (CSR) reporting. This way the "financing gap" can be filled with assets over 900 billion US dollars on Index funds which consider emerging countries as an attractive 
region to obtain sustainable returns. As a reference, China holds 7 billion US dollars on sustainable assets as of 2019 [5].

The vast literature regarding carbon emissions has been widely studied considering different perspectives. For the purpose of our study, note that environmental disclosures [6-8], CSR-ESG scores [9-11], GHG emissions [12,13] and carbon disclosure scores [3] have already been evidenced as factors that reduce Cost of Equity. Hence, there is evidence of a negative relation both taking into account ex-post returns [14] and ex-ante returns [12,15-17], thus reducing agency frictions and increasing the firm's legitimacy among stakeholders. However, according to Bui et al. [18], the majority of studies on sustainability and financial performance have focused on accounting-based performance ratios [19-21] or market returns in developed [22-24] and developing markets [25]. Therefore, the objective of this paper is to obtain empirical evidence on the relation between the Cost of Equity (COE) measured by Easton's [26] Price-Earnings growth model and firms' GHG emissions, environmental scores, and the assurance of sustainability reports, as proxies of sustainable behavior in emerging markets. COE is the percentage return demanded by investors in the long-run by sacrificing liquidity in the short-run or the rate required to discount firms' expected cash flows [10,27].

The sample consists of 929 publicly traded firms from 30 countries included in the Morgan Stanley Emerging Market Index from 2014 to 2019. Our study makes a relevant contribution to the existing literature since it uses a cross-country sample of 5328 firm-year observations in emerging markets, proving a positive relationship between Cost of Equity and GHG emissions while the opposite holds as regards to the link between.

The rest of this paper is structured as follows. Section 2 presents the theoretical framework, literature review and hypotheses development, Section 3 explains the research methodology, Section 4 discusses the results obtained and finally, Section 5 closes this paper with the conclusions and ideas for future research.

\section{Theoretical Framework, Literature Review and Hypotheses Development}

Under the Agency Theory framework, information asymmetry is expected to lead to greater stockholders' demands on stock returns [28] or decrease asymmetries between firms and capital providers by disclosing analyst reports [17]. As a result, firms' management may decide to disclose financial and non-financial information to eliminate these asymmetries to avoid company takeover and decrease monitoring costs borne by investors [29]. Firms ${ }^{\prime}$ management may possess private information on carbon emissions and strategies not disclosed to stakeholders [30] but equity markets can play an important role in monitoring firms' environmental disclosures, also on emerging economies [31]. On the other hand, carbon information disclosures increase firms' transparency and decrease financial risk [32] helping firms to reduce information asymmetries [15] and being carbon disclosures as relevant variable to analyze firms' risk profiles [22]. GHG information is one aspect within the environmental disclosures that companies publish [21], and existing research proves that the voluntary disclosure of GHG emissions has a negative effect on equity value [24].

The Stakeholder Theory provides a framework that establishes that firms are accountable not only to investors but also to all stakeholders, since the latter have different demands. Thus, the company needs to provide information and avoid conflicts [33]. Moreover, the firm's purpose is to satisfy internal and external stakeholders' demands by disclosing ESG activities and increment financial performance [25], reduce adverse events such as product recalls, strikes, and environmental scandals by having good relations with stakeholders [7]. In this sense, firms' carbon disclosures reduce frictions by providing extensive information to stakeholders [18]. Several empirical studies have analyzed the relation between carbon disclosure scores and COE. Albarrak et al. [16] analyze carbon information disclosures through social networks and conclude that Icarbon (number of tweets related to Carbon information disseminated by firms through Twitter) reduces COE. Moreover, stakeholders pay additional attention to Icarbon disclosures compared to more general environmental scores. Contrary, in an emerging market setting, the analysis between ESG scores from 
Malaysian firms and $\mathrm{COE}$ indicates a non-significant relation probably due to investor's low confidence in environmental scores [25] which is in line with Feng et al.'s [34] results.

The Legitimacy Theory can also provide a suitable framework for our research. Organizations are categorized as legitimate when audiences perceive them as institutions defending social principles and values and not just private firms' interests [35]. Moreover, disclosing environmental and social activities improves the firm's reputation amongst a wider group of stakeholders [36] and a social contract with stakeholders is accomplished when carbon information is disclosed [37] as well other information on ESG, especially if this information is externally assured. However, companies are severely penalized by market participants when GHG emissions are not fully disclosed [22]. Along the same lines, the study of carbon information disclosure by Chinese firms and market value considering $\mathrm{COE}$ indicates that carbon disclosures reduce $\mathrm{COE}$ incrementing share's liquidity, market value so that one may conclude that investing in carbon management activities leads to more financial benefits [38]. In addition, media reporting leads to a quality increase in carbon information disclosure and to a reduction in COE of Chinese polluting-listed firms, improving the firms' image and legitimacy to different stakeholders [13]. In fact, evidence obtained indicates that disseminating carbon information with Twitter shows that firms are committed to enhance their legitimacy by helping capital providers to evaluate firms' risk to improve their investment decisions [16].

Last but not least, the Voluntary Disclosure Theory states that good firm performers possess and disclose voluntarily information compared to results provided by poor performers and help stakeholders to take decisions $[1,39,40]$. Based on the abovementioned, the contribution by Albarrak et al. [16] considering a sample of US firms indicates that carbon disclosures disseminated by Twitter help investors know firms' carbon inventory and provide valuable information for investment decisions. Similarly, Lemma et al. [3] with a sample of South African listed firms conclude that carbon disclosures help reduce firms' risk and avoid pessimistic reactions on market participants in the Johannesburg Securities Exchange.

Existing research has used the above mentioned frameworks to analyze the impact of sustainable behavior on COE. This relation between has been studied considering developed and developing economies. As a reference, the voluntary disclosure of CSR from North America listed firms demonstrates a negative relation with COE according to Sharfman and Fernando [6], Dhaliwal et al. [9] and El Ghoul et al. [10]. Moreover, considering multi-country samples, the link between CSR and COE is more significant in stakeholder-oriented countries [41] or countries with weak governance levels [8] where there is an increasing trend of Social Responsible Investment funds investing in sustainable firms. The link between Corporate Environmental Responsibility (CER) and COE from 30 countries, shows also a negative relation [7]. Regarding GHG emissions, the direct link between carbon intensity and COE is also evidenced taking into account a sample of Korean listed firms [12], confirming that capital providers penalize polluting companies. Along the same lines yet, considering a sample of 34 countries, results show that companies' GHG emissions and $\mathrm{COE}$ are positive and the latter relation is more pronounced in developing economies [18].

The Carbon Disclosure Project (CDP) is an important reference for measuring carbon emissions including different topics such as firms' management and inventory emission, GHG accounting, and climate change. The responses are obtained through questionnaires and promote transparency and commitment by organizations to fight climate change [32,42]. Different contributions consider CDP data in an emerging economies setting. For instance, the relation between carbon disclosures and COE with a sample of South African firms confirms that $\mathrm{COE}$ is negatively related to voluntary disclosures since the quality of carbon information disclosures rewards companies with cheaper equity costs [3]. Similarly, but from a different country perspective, the study of carbon disclosures, $\mathrm{COE}$ and media reporting taking into consideration a sample of highly-polluting firms from Shanghai and Shenzhen equity exchanges, highlights that the disclosure of financial and non-financial 
carbon information are negatively related with COE as well as media reporting with COE [13]. The negative relation between the quality of carbon emission disclosures and $\mathrm{COE}$ is again corroborated considering as a moderating variable the different levels of marketization in the regions of the Chinese economy [15]. Contrary to the latter literature, the relation between GHG emission intensity and COE remains positive taking into account a sample of firms from developed and developing countries as in Bui et al. [18].

Following previous literature, we propose our first hypothesis:

Hypothesis 1 (H1): Cost of Equity is positively influenced by GHG emissions.

Sharfman and Fernando [6] conclude that improving and disclosing environmental risk management information leads to a reduction in COE. Taking into consideration multi-country sample studies, Ng and Rezaee [43] find a negative relation between Environmental and Governance sustainability performance with COE, and El Ghoul et al. [7] estimate that CER Scores decrease firms' environmental expenses thereby decreasing COE. Gupta [8] demonstrates that good environmental practices lead to a reduction in COE especially in weak-governance countries facilitating investment options for Social Responsible Investment Funds. Raimo et al. [44] also confirm the inverse relation between ESG disclosures from Food and Beverage sector firms and COE. Lastly, in an emerging market setting such as Malaysia, Shad et al. [14] evidence that sustainability and economic reporting from the oil and gas industry decrease COE. Therefore, we present the second hypothesis of our study:

Hypothesis 2 (H2): Cost of Equity is negatively influenced by firms' ESG scores.

Stand-Alone reports (also called sustainability or CSR reports) offer information about the firm's commitment, endeavors, and policy indicators related to sustainable development required in the decision-making process of the company's stakeholders [45]. The assurance of CSR reports gives higher credibility to those reports as an external verification process $[46,47]$ especially in countries with great stakeholder demand for sustainable practices [48]. The negative relation between COE and CSR assurance has been evidenced by existing research. For example, Casey and Grenier [49] conclude that the voluntary assurance of CSR report reduces COE and the reduction increments when the assurer is an accountancy firm. Moreover, Martinez-Ferrero and Garcia-Sanchez [50] evidence lower COE when the assurance provider is a Big4 audit firm. Finally, Weber [51] analyzes the assurance practice and Global Reporting Initiative (GRI) reporting levels, concluding that poor CSR performers reporting at high GRI levels decrease COE when their CSR report is assured. Therefore, we present our third and final hypotheses:

Hypothesis 3 (H3): Cost of Equity is negatively influenced by the assurance of CSR Reports.

\section{Research Methodology}

The Morgan Stanley Emerging Market Index includes over 1300 large and mid-cap securities from 27 emerging countries across the world. Data from companies belonging to that index were retrieved from the Thomson Reuters Eikon database including sustainable and control variables as well as the data from International Broker Estimates (I-B-E-S) required to compute the Cost of Equity. The period covered is from 2014 to 2019.

Consequently, an unbalanced dynamic panel data of 5328 firm-year observations and 929 publicly trading firms was obtained with a market value greater than 4 billion US dollars. Our methodological approach uses Generalized Method of Moments (GMM) by Blundell and Bond [52]. Furthermore, to provide robustness, the Hansen's Test is implemented to measure if there is over-identification of variables as well as the Arellano and Bond's test for autocorrelation of errors. The GMM model is used to mitigate endogeneity defined as the causal correlation between the explanatory variable with the error term [53], and has already been implemented by Martinez-Ferrero and Garcia Sanchez [50]; 
El Ghoul et al. [7] and Gupta [8]. Lastly, we lagged the dependent variable according to Nelling and Webb [54] and El Ghoul et al. [7].

The model is as follows:

$$
\begin{aligned}
\mathrm{COE}_{i t} & =\beta_{0}+\beta_{1} \mathrm{COE}_{i(t-1)}+\beta_{2} \text { Co2Emissions }_{i t}+\beta_{3} \text { EnvDisclosure }_{i t}+\beta_{4} \text { CSR Assurance }+\beta_{5} \text { BETA }_{i t} \\
& +\beta_{6} \text { BTM }_{i t}+\beta_{7} \text { ROA }_{i t}+\beta_{8} \text { SIZE }_{i t}+\sum_{j=1}^{12} \beta_{j} \text { Industry }_{i t}+\sum_{j=1}^{6} \beta_{j} \text { Year }_{i t}+\sum_{j=1}^{6} \beta_{j} \text { Regions }_{i t}+\varepsilon_{i t}
\end{aligned}
$$

Table 1 details the number of observations according to the six global regions defined by Sethi et al. [48]. The three most represented emerging regions in our sample are: East Asia capturing the majority of observations (55.74\%), the South Asian region with $17.79 \%$ of the total observations and Latin America with $10.47 \%$.

\begin{tabular}{|c|c|c|}
\hline & Observations & Percentages \\
\hline $\begin{array}{c}\text { East Asia } \\
\text { (China, South Korea, Hong Kong, Philippines, Taiwan) }\end{array}$ & 2970 & $55.74 \%$ \\
\hline $\begin{array}{c}\text { Eastern Europe and Central Asia } \\
\text { (Cyprus, Czech Republic, Greece, Hungary, Poland, } \\
\text { Russia, Turkey) }\end{array}$ & 384 & $7.21 \%$ \\
\hline $\begin{array}{c}\text { Latin America and Caribbean } \\
\text { (Argentina, Bermuda, Brazil, Cayman Island, Chile, } \\
\text { Colombia, Mexico, Peru) }\end{array}$ & 558 & $10.47 \%$ \\
\hline $\begin{array}{c}\text { Middle East and North Africa } \\
\text { (Egypt, Qatar, Saudi Arabia, United Arab Emirates) }\end{array}$ & 222 & $4.17 \%$ \\
\hline $\begin{array}{c}\text { South Asia } \\
\text { (India, Indonesia, Malaysia, Pakistan, Thailand) }\end{array}$ & 948 & $17.79 \%$ \\
\hline $\begin{array}{l}\text { Sub-Saharan Africa } \\
\text { (South Africa) }\end{array}$ & 246 & $4.62 \%$ \\
\hline Total & 5328 & $100 \%$ \\
\hline
\end{tabular}

Table 1. Firm year observations for Regions.

Table 2 shows the number of observations considering industrial sectors as in Cordova et al. [55]. The financial sector provides $21.06 \%$ of observations while industrials and energy clusters include $17.79 \%$ and $12.50 \%$ of the total observations, respectively.

Table 2. Firm-year observations per Industries.

\begin{tabular}{ccc}
\hline & Observations & Percentages \\
\hline Consumer Discretionary & 576 & $10.81 \%$ \\
Consumer Staples & 492 & $9.23 \%$ \\
Energy & 666 & $12.50 \%$ \\
Financials & 1122 & $21.06 \%$ \\
Healthcare & 264 & $4.95 \%$ \\
Industrials & 948 & $17.79 \%$ \\
Information Technology & 270 & $5.07 \%$ \\
Materials & 72 & $1.35 \%$ \\
Real Estate & 282 & $5.29 \%$ \\
Telecommunication Services & 222 & $4.17 \%$ \\
Transportation & 228 & $4.28 \%$ \\
Utilities & 186 & $3.49 \%$ \\
Total & 5328 & $100 \%$ \\
\hline
\end{tabular}

\subsection{Dependent Variable}

COE is the dependent variable in the GMM models. It is computed taking into account the Price-Earnings Growth Model by Easton [26]. It considers the forecasted earnings per 
share for year 2, earnings per share for year 1 divided by the target price for a specific firm, and time period. Moreover, the model considers the assumption of zero dividend payments and no abnormal earnings growth. Botosan and Plumlee [56] indicate that this model is predictable and consistent with leverage, market risks, growth, and residual returns and Pastor et al. [57] demonstrate that ex-ante results capture time variations in expected returns. This model is implemented by Kim et al. [12], Li et al. [15], Yao and Liang [17] and Bui et al. [18].

$$
C O E_{i t}=\sqrt{\frac{E P S_{i t+2}-E P S_{i t+1}}{P_{i t}}}
$$

\subsection{Sustainable and Control Variables}

Regarding sustainable variables, and as explained in the hypotheses development section, carbon emissions is expected to have a positive sign according to Kim et al. [12] and Bui et al. [18], whereas ESG Scores is expected to have a negative sign (as in Sharfam and Fernando [6]; El Ghoul et al. [7]; Gupta [8], and Shad et al. [14] as well CSR assurance (Martinez-Ferrero and Garcia-Sanchez [50] and Weber [51].

Concerning control variables, Beta is expected to have a positive coefficient since higher systematic risk should lead to higher COE as in Albarrak et al. [16] and Li et al. [15]. We also consider size as a control variable according to Dhaliwal et al. [9,41] and Yao and Liang [17], return on assets (ROA) to capture firms' profitability as in Li et al. [13]; Gupta [8]; Bui et al. [18] and Shad et al. [14] and finally Book-to-Market as in Kim et al. [12]; El-Ghoul et al. [7]; Li et al. [15] and Albarrak et al. [16].

Table 3 describes the variables studied in our model.

Table 3. Variable Description.

\begin{tabular}{|c|c|}
\hline Variable-Label & Description \\
\hline Cost of Equity-COE & Calculated according to Easton (2004) Price Earnings Growth Model—Continuous Variable \\
\hline Beta & Company's Systematic Risk-Continuous Variable \\
\hline Book to Market & Book Value divided by Market Value of Firm-Continuous Variable \\
\hline Return on Assets & Net Earnings divided by Total Assets-Continuous Variable \\
\hline Size & Natural Logarithm of Market Capitalization-Continuous Variable \\
\hline Carbon Emissions & $\begin{array}{l}\text { Natural Logarithm of Carbon Emissions measured in tones disclosed by firms equivalent to the sum of } \\
\text { Scope } 1 \text { (direct emissions) and Scope } 2 \text { (indirect emissions) - Continuous Variable. }\end{array}$ \\
\hline Environmental Score & $\begin{array}{l}\text { Sustainable score disclosed by firms' technology implemented to reduce environmental expenses, } \\
\text { develop eco-friendly products and services and reduce negative externalities to stakeholders-value } \\
\text { between } 0 \% \text { to } 100 \% \text { - Continuous variable }\end{array}$ \\
\hline CSR Assurance & $\begin{array}{c}\text { The CSR report can be assured by a third-party to give it more credibility-Categorical Variable (1 if CSR } \\
\text { Report is Assured, } 0 \text { otherwise) }\end{array}$ \\
\hline Regions & Six Global Regions according to Sethi et al. [48]—Categorical Variable \\
\hline Industry & $\begin{array}{l}\text { Twelve industrial sectors according to Cordova et al. [55] (1 if that specific industry sector is considered, } \\
\text { 0 otherwise)-Categorical Variable }\end{array}$ \\
\hline Year & Time period between 2014 to 2019 ( 1 if that year is considered, 0 otherwise) —Categorical Variable \\
\hline
\end{tabular}

Table 4 shows the descriptive statistics for each of the variables. For instance, the average mean for $\mathrm{COE}, \mathrm{CO}_{2}$ emissions and Environmental Disclosures is 14.5, 12.51, and $40.4 \%$. 
Table 4. Descriptive Statistics.

\begin{tabular}{ccccccc}
\hline Variable & Mean & Std Dev & Max & Min & 25th Perc & 50th Perc \\
\hline COE & 0.1455888 & 0.18763 & 3.065668 & 0 & 0.0335808 & 0.1010091 \\
BETA & 0.8352038 & 0.5668023 & 2.962036 & 0.50104620 & 0.4526645 & 0.8714394 \\
SIZE & 8.949815 & 1.011018 & 13.10956 & 4.18735 & 8.2604 & 8.846894 \\
BTM & 12.72248 & 47.06825 & 687.5413 & -8.648931 & 0.6042406 & 1.389203 \\
ROA & 0.0604599 & 0.0741281 & 1.688215 & -0.7492324 & 0.0162838 & 0.0441098 \\
$\mathrm{CO}_{2}$ emissions & 12.50739 & 2.534687 & 19.63255 & 2.639057 & 10.61965 & 12.26111 \\
Env Disclosures & 0.4044543 & 0.2355073 & 0.5564804 & 0 & 0.000000000000971 & 0.5372499 \\
CSR Assurance & 0.7601053 & 0.4270592 & 1 & 0 & 1 & 1 \\
\hline
\end{tabular}

Table 5 presents the Pearson correlation matrix. Results indicate a positive relation between carbon emissions and COE with a significance level of $1 \%$. The Variance of Inflation Factor (VIF) is 2.56 so there is no evidence of multicollinearity among the independent variables because it is well below the benchmark of 10 as in Matsumura et al. [22]; Griffin et al. [24] and Shad et al. [14].

Table 5. Pearson Correlation Coefficients.

\begin{tabular}{|c|c|c|c|c|c|c|c|c|c|c|c|c|c|c|c|}
\hline & 1 & & 2 & & 3 & & 4 & & 5 & & 6 & & 7 & & 8 \\
\hline $\mathrm{COE}$ & 1 & & & & & & & & & & & & & & \\
\hline BETA & -0.0967 & $* * *$ & 1 & & & & & & & & & & & & \\
\hline BTM & -0.0329 & $* *$ & 0.0133 & & 1 & & & & & & & & & & \\
\hline $\mathrm{ROA}$ & -0.0229 & * & -0.1409 & $* * *$ & -0.0574 & $* * *$ & 1 & & & & & & & & \\
\hline SIZE & 0.0026 & & -0.0082 & & -0.015 & & 0.0668 & $* * *$ & 1 & & & & & & \\
\hline $\mathrm{CO}_{2}$ emissions & 0.0637 & $* * *$ & 0.0034 & & 0.0634 & $* * *$ & -0.0365 & $* *$ & 0.2189 & $* * *$ & 1 & & & & \\
\hline Env Disclosures & 0.1924 & $* * *$ & -0.0252 & * & -0.0166 & & -0.013 & & 0 & & -0.1594 & $* * *$ & 1 & & \\
\hline CSR Assurance & 0.2016 & $* * *$ & -0.0238 & * & -0.014 & & -0.0276 & $* *$ & 0.0257 & * & -0.0348 & $* *$ & 0.9651 & $* * *$ & 1 \\
\hline
\end{tabular}

Coefficients with asterisk are statistically significant ${ }^{* *} 1 \% * * 5 \% * 10 \%$. Variance of Inflation Factor (VIF)-2.56.

\section{Results}

Based on the regression model, we proceeded to calculate our results implementing the Generalized Method of Moments and thereby contrasted our three hypotheses fragmented into three panels explained in Table 6.

Table 6. Results of the Generalized Method of Moments (GMM) Model.

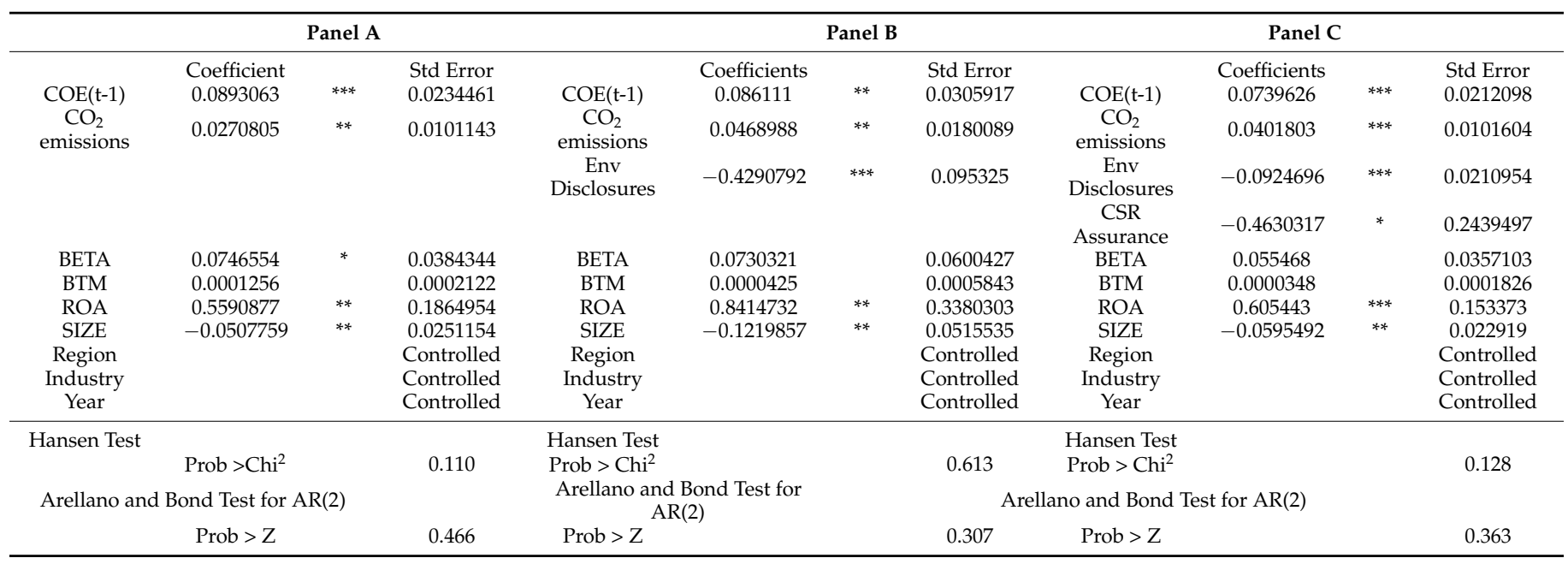

Generalized Method of Moments-Two Step Statistically Significant at * $10 \% * * 5 \% * * * 1 \%$.

Firstly, Panel A indicates a positive relation between carbon emissions (0.027) and COE with a significance level of $5 \%$, which is also ratified in Panel B and Panel C shows a significance level of $1 \%$ (when the other hypotheses are also tested). Therefore, regarding our first hypothesis, we can conclude that firms with higher carbon emission intensity 
are penalized with greater equity cost. Our result is in line with Kim et al. [12] and Bui et al. [18].

Secondly, Panel B shows a negative relation between environmental disclosures $(-0.4290)$ and COE with a significance level of $1 \%$ which is also confirmed by Panel C. Consequently, we do not reject the second hypotheses, arriving at consistent findings with El Ghoul et al. [7] and Gupta [8], in the sense that the investors tend to accept less returns from sustainable companies, who are awarded with a lower COE.

Thirdly, Panel C shows that assuring the CSR reports decrease COE $(-0.463)$ with a significance level of $10 \%$. Thus, we have no evidence for rejecting the third hypothesis, similarly to the findings obtained by Martinez-Ferrero and Garcia-Sanchez [50] and Weber [51]. This evidence corroborates that in emerging markets higher credibility of CSR reports also leads to a reduction in COE.

Concerning control variables, the coefficient in Return On Assets in Panel A and B is positive with a significance level of $5 \%$, lowering to a significance level of $1 \%$ in Panel C. Therefore, the results are consistent with Li et al. [13]; Gupta [8] and El Ghoul et al. [7]. Size is always negatively related as in Panel A, B and C with a significance level of 5\% as in Sharfman and Fernando [6], Dhaliwal et al. [41], Ng and Rezaee [43], and Yao and Liang [17]. This evidence indicates that firms with greater capitalization decrease their $\mathrm{COE}$ and are perceived as less risky investments $[44,56]$. The Beta's coefficient $(0.074)$ is only significant on Panel A at the 10\% level as in Ahmed et al. [11], Yao and Liang [17] and Bui et al. [18] and therefore firms' systematic risk is related with COE consistent with Sharpe [58] and Raimo et al. [44]. Lastly, Book to Market is not significant in any of the Panels.

Additionally, we implement the Hansen Test in Panel A (0.110), Panel B (0.613), and Panel C (0.128). As a consequence, we do not reject the hypotheses of over-identifying restriction and the instruments are valid. The Arellano and Bond Test shows rather similar values for Panel A (0.466), Panel B (0.307), and Panel C (0.363) and in the three panels the hypotheses of no serial correlation of errors in our model are accepted taking into account that the probability of $\mathrm{Z}$ value is greater than 0.05 .

\section{Conclusions}

Our research analyzes the interaction of carbon emissions, environmental disclosures and assurance of CSR reports with COE using a global sample of 30 countries, with 929 firms included in the Morgan Stanley Emerging Market Index. The evidence obtained indicates that higher carbon emissions increase COE premiums which is in line with Kim et al. [12] and Bui et al. [18]. We also find that the effects of higher environmental disclosures $[7,8,44]$ and the assurance of stand-alone reports $[50,51]$ is opposite, in the sense that these two factors tend to lead to a lower COE. Moreover, our empirical results are robust since the Generalized Method of Moments is implemented to address endogeneity according to Blundell and Bond [52].

This study has limitations derived from the limited information of Carbon Disclosure Scores provided by the companies to the Carbon Disclosure Project database which represents an important source of carbon management data obtained through reports, surveys or other sources that are compiled and used by researchers $[3,18]$.

This research paper provides an innovative and valuable contribution to the existing literature and also to economic agents and market participants. Firstly, it considers the relation of GHG emissions and COE in an emerging market setting whereas the majority of studies analyze the relation between carbon emissions and accounting or capital-market ratios. Secondly, our findings support the assurance of non-financial reports as a means to decrease agency costs and help create a social contract among corporate management and stakeholders. Thirdly, carbon emissions represent a risk that must be considered when capital providers analyze the situation of the firm, especially if located in countries known as the "rising power" [3] or financial information is opaque [8]. 
Therefore, our research suggests that companies could take advantage of voluntary carbon disclosures and try to reduce their pollutions levels to reduce their cost of capital, leading to a more sustainable planet and helping to achieve the SDG 13. Our findings also support that firms invest in better transparency strategies regarding ESG with more disclosures and external assurance are rewarded with lower equity costs. Policymakers and regulators will find our research useful to support in front of companies any new voluntary or even compulsory measure that they may decide to introduce to improve corporate environmental reporting by highlighting our findings that the cost of capital is reduced with lower emissions and better environmental disclosures. Regarding future research studies, we propose the analysis of COE, ESG and Carbon Emission disclosures from the Food and Beverage sector expanding our sample to developed and developing countries [44]. Another important context is the implementation of the Integrated Report as a sustainable practice disclosed by high Carbon Emission firms and its relation with COE; this may increase accountability especially on stakeholder-oriented countries [59]. Additionally, the quality of CSR reporting disclosed by Carbon Intensive firms and its relation with COE considering analyst coverage as a moderating variable, is in line with the Agency and Voluntary Disclosure theory as in Yao and Liang [17]. Lastly, the relation between Greenhouse Gas Emissions, non-financial quality information and female participation on the Board of Directors may represent another research avenue as in Hollindale et al. [36].

Author Contributions: Conceptualization, R.G.-J. and A.Z.-G.; Methodology, R.G.-J. and A.Z.-G.; Software, R.G.-J.; Validation, R.G.-J. and A.Z.-G.; Formal Analysis, R.G.-J.; Investigation, R.G.-J.; Resources, R.G.-J.; Data Curation, R.G.-J. and A.Z.-G.; Writing-Original Draft Preparation, R.G.-J. and A.Z.-G.; Writing-Review \& Editing, A.Z.-G.; Visualization, R.G.-J. and A.Z.-G.; Supervision, A.Z.-G. All authors have read and agreed to the published version of the manuscript.

Funding: This research received no external funding.

Institutional Review Board Statement: Not applicable.

Informed Consent Statement: Not applicable.

Data Availability Statement: Not applicable.

Conflicts of Interest: The authors declare no conflict of interest.

\section{References}

1. Zhang, Y.-J.; Liu, J.-Y. Overview of Research on Carbon Information Disclosure. Front. Eng. Manag. 2020, 7, 47-62. [CrossRef]

2. United Nations Statistic Division. Sustainable Development Goals Overview. Available online: https://unstats.un.org/sdgs/ report/2019/goal-13/ (accessed on 15 October 2020).

3. Lemma, T.T.; Feedman, M.; Mlilo, M.; Park, J.D. Corporate Carbon Risk, Voluntary Disclosure, and Cost of Capital: South African Evidence. Bus. Strategy Environ. 2019, 28, 111-126. [CrossRef]

4. Zheng, X.; Streimikiene, D.; Balenzetis, T.; Mardani, A.; Cavallaro, F.; Liao, H. A review of greenhouse gas emissions profiles, dynamics, and climate change mitigation efforts across the key climate change players. J. Clean. Prod. 2019, 234, 1113-1133. [CrossRef]

5. United Nations Conference on Trade and Development. World Investment Report, 2020 International Production beyond the Pandemic. Available online: https://unctad.org/system/files/official-document/wir2020_en.pdf (accessed on 17 October 2020).

6. Sharfman, M.P.; Fernando, C.S. Environmental risk management and the cost of capital. Strateg. Manag. J. 2008, 29, 569-592. [CrossRef]

7. El Ghoul, S.; Guedhami, O.; Kim, H.; Park, K. Corporate Environmental Responsibility and the Cost of Capital: International Evidence. J. Bus. Ethics 2018, 149, 335-361. [CrossRef]

8. Gupta, K. Environmental Sustainability and Implied Cost of Equity: International Evidence. J. Bus. Ethics 2018, 147, 343-365. [CrossRef]

9. Dhaliwal, D.; Li, O.; Tsang, A.; Yang, Y. Voluntary Nonfinancial Disclosure and the Cost of Equity Capital: The Initiation of Corporate Social Responsibility Reporting. Account. Rev. 2011, 86, 59-100. [CrossRef]

10. El Ghoul, S.; Guedhami, O.; Kwok, C.; Mishra, D. Does Corporate Social Responsibility affect the cost of capital? J. Financ. Bank. 2011, 35, 2388-2406. [CrossRef]

11. Ahmed, A.; Eliwa, Y.; Power, D. The impact of corporate social and environmental practices on the cost of equity capital: UK evidence. Int. J. Account. Inf. Manag. 2019, 27, 425-441. [CrossRef]

12. Kim, Y.; An, H.; Kim, J. The effect of carbon risk on the cost of equity capital. J. Clean. Prod. 2015, 93, 279-287. [CrossRef] 
13. Li, L.; Liu, Q.; Tang, D.; Xiong, J. Media reporting, carbon information disclosure, and the cost of equity financing: Evidence from China. Environ. Sci. Pollut. Res. 2017, 24, 9447-9459. [CrossRef] [PubMed]

14. Shad, M.; Lai, F.; Shamin, A.; McShane, M. The efficacy of sustainability reporting towards cost of debt and equity reduction. Environ. Sci. Pollut. Res. 2020, 27, 22511-22522. [CrossRef] [PubMed]

15. Li, L.; Liu, Q.; Wang, J. Carbon Information Disclosure, Marketization, and Cost of Equity Financing. International. J. Environ. Res. Public Health 2019, 16, 150. [CrossRef] [PubMed]

16. Albarrak, M.; Mohammed, S.; Elnahass, M.; Salama, A. The effect of carbon dissemination on cost of equity. Bus. Strategy Environ. 2019, 28, 1179-1198. [CrossRef]

17. Yao, S.; Liang, H. Analyst following, Environmental Disclosure and Cost of Equity: Research based on Industry Classification. Sustainability 2019, 11, 300. [CrossRef]

18. Bui, B.; Moses, O.; Houqe, M. Carbon disclosure, emission intensity and cost of equity capital: Multi-country evidence. Account. Financ. 2020, 60, 47-71. [CrossRef]

19. Clarkson, P.; Li, Y.; Richardson, G.; Vasvari, F. Does it really pay to be green? Determinants and consequences of proactive environmental strategies. J. Account. Public Policy 2011, 30, 122-144. [CrossRef]

20. Gallego-Alvarez, I.; Segura, L.; Martinez-Ferrero, J. Carbon emission reduction: The impact on the financial and operational performance of international companies. J. Clean. Prod. 2015, 103, 149-159. [CrossRef]

21. Borghei, Z.; Leung, P.; Guthrie, J. Voluntary greenhouse gas emission disclosure impacts on accounting-based performance: Australian evidence. Australas. J. Environ. Manag. 2018, 25, 321-338. [CrossRef]

22. Matsumura, E.; Prakash, R.; Vera-Munoz, S. Firm-value effects of Carbon Emissions and Carbon Disclosures. Account. Rev. 2014, 89, 695-724. [CrossRef]

23. Saka, C.; Oshika, T. Disclosure effects, carbon emissions and corporate value. Sustain. Account. Manag. Policy J. 2014, 5, 22-45. [CrossRef]

24. Griffin, P.; Lont, D.; Sun, E. The Relevance to Investors of Greenhouse Gas Emission Disclosures. Contemp. Account Res. 2017, 34, 1265-1297. [CrossRef]

25. Atan, R.; Alam, M.; Said, J. The impacts of environmental, social, and governance factors on firm performance. Manag. Environ. Qual. 2018, 29, 182-294. [CrossRef]

26. Easton, P. PE Ratios, PEG Ratios, and estimating the Implied Expected Rate of Return on Equity Capital. Account. Rev. 2004, 79, 73-95. [CrossRef]

27. Garzon-Jimenez, R.; Zorio-Grima, A. Corporate Social Responsibility and Cost of Equity: Literature Review and Suggestions for future research. J. Bus. Account. Financ. Perspect. 2020, 2. [CrossRef]

28. Easley, D.; O'hara, M. Information and the cost of capital. J. Financ. 2004, 59, 1553-1583. [CrossRef]

29. Healy, P.M.; Palepu, K.G. Information asymmetry, corporate disclosure, and the capital markets: A review of the empirical disclosure literature. J. Account. Econ. 2001, 31, 405-440. [CrossRef]

30. Luo, L.; Tang, Q. Does voluntary carbon disclosure reflect underlying carbon performance? J. Contemp. Account. Econ. 2014, 10, 191-205. [CrossRef]

31. Gupta, S.; Goldar, B. Do stock markets penalize environment-unfriendly behavior? Evidence from India. Ecol. Econ. 2005, 52, 81-95. [CrossRef]

32. Gonzalez-Gonzalez, J.M.; Ramirez, C.Z. Voluntary Carbon Disclosure by Spanish Companies: An Empirical Analysis. Int. J. Clim. Chang. Strateg. Manag. 2016, 8, 57-79. [CrossRef]

33. Roberts, R. Determinants of corporate social responsibility disclosure: An application of stakeholder theory. Account. Organ. Soc. 1992, 6, 595-612. [CrossRef]

34. Feng, Z.; Wang, M.; Huang, H. Equity Financing and Social Responsibility: Further International Evidence. Int. J. Account. 2015, 50, 247-280. [CrossRef]

35. Miranda, S.; Cruz-Suarez, A.; Roman-Prado, M. Relationship between Legitimacy and Organizational Success; Springer: Cham, Switzerland, 2018; ISBN 978-3-319-75990-6.

36. Hollindale, J.; Kent, J.; Routledge, J.; Chapple, L. Women on boards and greenhouse gas emissions disclosures. Account. Financ. 2019, 59, 277-308. [CrossRef]

37. Hahn, R.; Reimsbach, D.; Schiemann, F. Organizations, Climate Change, and Transparency: Reviewing the Literature on Carbon Disclosure. Organ. Environ. 2015, 28, 80-102. [CrossRef]

38. Li, L.; Yang, Y.; Tang, D. Carbon Information Disclosure of Enterprises and their Value Creation through Market Liquidity and Cost of Equity Capital. J. Ind. Eng. Manag. 2015, 8, 137-151. [CrossRef]

39. Verrecchia, R.E. Discretionary Disclosure. J. Account. Econ. 1983, 5, 179-194. [CrossRef]

40. Clarkson, P.; Li, Y.; Richardson, G.; Vasvari, F.P. Revisiting the relation between environmental performance and environmental disclosure: An empirical analysis. Account. Organ. Soc. 2008, 33, 303-327. [CrossRef]

41. Dhaliwal, D.; Li, O.; Tsang, A.; Yang, Y. Corporate social responsibility disclosure and the cost of equity capital: The roles of stakeholder orientation and financial transparency. J. Account. Public Policy 2014, 33, 328-355. [CrossRef]

42. Li, D.; Huang, M.; Ren, S. Environmental Legitimacy, Green Innovation and Corporate Carbon Disclosure: Evidence from CDP China 100. J. Bus. Ethics 2018. [CrossRef]

43. Ng, A.; Rezaee, Z. Business Sustainability performance and cost of equity capital. J. Corp. Financ. 2015, 34, 128-149. [CrossRef] 
44. Raimo, M.; de Nuccio, E.; Giakoumelou, A.; Petruzella, F.; Vitolla, F. Non-financial information and cost of equity capital: An empirical analysis in the food and beverage industry. Br. Food J. 2019. [CrossRef]

45. Garcia-Sanchez, I. Corporate Social Responsibility and Assurance: The State of Art. Span. Account. Rev. 2020. [CrossRef]

46. Zorio, A.; García-Benau, M.A.; Sierra, L. Sustainability development and the quality of assurance reports: Empirical evidence. Bus. Strategy Environ. 2013, 22, 484-500. [CrossRef]

47. Sierra-García, L.; Zorio-Grima, A.; García-Benau, M.A. Stakeholder engagement, corporate social responsibility and integrated reporting: An exploratory study. Corp. Soc. Responsib. Environ. Manag. 2015, 22, 286-304. [CrossRef]

48. Sethi, S.P.; Martell, T.F.; Demir, M. Enhancing the Role and Effectiveness of Corporate Social Responsibility (CSR) Reports: The Missing Element of Content Verification and Integrity Assurance. J. Bus. Ethics 2017, 144, 59-82. [CrossRef]

49. Casey, R.J.; Grenier, J.H. Understanding and contributing to the enigma of corporate social responsibility (CSR) assurance in the United States. Auditing 2015, 34, 97-130. [CrossRef]

50. Martinez-Ferrero, J.; Garcia-Sanchez, I.-M. Sustainability Assurance and cost of capital: Does assurance impact on credibility of corporate social responsibility information? Bus. Ethics Eur. Rev. 2017, 26, 223-239. [CrossRef]

51. Weber, J. Corporate Social Responsibility disclosure level, external assurance and cost of equity capital. J. Financ. Report. Account. 2018, 16, 694-724. [CrossRef]

52. Blundell, R.; Bond, S. Initial conditions and moment restrictions in dynamic panel data models. J. Econom. 1998, 87, 115-143. [CrossRef]

53. Li, F. Endogeneity in power CEO: A survey an experiment. Investig. Anal. J. 2016, 45, 149-162. [CrossRef]

54. Nelling, E.; Webb, E. Corporate social responsibility and financial performance: "the "virtuous circle" revisited. Rev. Quant. Financ. Account. 2009, 32, 197-209. [CrossRef]

55. Cordova, C.; Zorio-Grima, A.; Merrello, P. Carbon Emissions by South American Companies: Driving Factors for Reporting Decisions and Emissions Reduction. Sustainability 2018, 10, 2411. [CrossRef]

56. Botosan, C.A.; Plumlee, M.A. Assessing alternative proxies for the expected risk premium. Account. Rev. 2005, 80, 21-53. [CrossRef]

57. Pastor, L.; Sinha, M.; Swaminathan, B. Estimating the Intertemporal Risk-Return Tradeoff Using the Implied Cost of Capital. J. Financ. 2008, 63, 2859-2897. [CrossRef]

58. Sharpe, W. Capital Asset Prices: A Theory of Market Equilibrium under Conditions of Risk. J. Financ. 1964, 19, 425-442. [CrossRef]

59. Zhou, S.; Simnet, R.; Green, W. Does Integrated Reporting Matter to the Capital Market? Abacus 2017, 53, 94-132. [CrossRef] 